\title{
Bioequivalence and Bioavailability of Receptors Dopamine (D2) and Serotonin in the Action of Antipsychotic Drugs
}

\section{Butnariu $\mathbf{M}^{*}$}

Banat's University of Agricultural Sciences and Veterinary Medicine "King Michael I of Romania" Timisoara, Romania 300645, Timis, Romania

First, who studied of occupancy degree the receptors D2 (D2Rprotein that, in humans, is encoded by the DRD2 gene) it was Farde and colleagues in 1980 who observed that most antipsychotics, with the exception of clozapine, have a high occupancy rate, receptors D2 (70\% or even more) to clinical doses used. The following studies have demonstrated that there is a "therapeutic window" for most antipsychotics with a locking of $60-65 \%$ of the receptors, necessary to obtain optimal response antipsychotic, and occupancy of more than of $80 \%$ it is associated with Extrapyramidal Symptoms (EPS) [1].

Blocking the receptors D2 can adequately explain the beneficial effects the typical antipsychotics on positive symptoms of acute the psychotic episode. Blocking the receptors D2 contribute to the antipsychotic effect of the serotonin-dopamine receptor antagonists.

EPS and increased prolactin levels caused by antipsychotics can be satisfactorily explained of the antagonism of dopaminergic neurotransmission mediated by receptors D2 in the striatum (which is part of the extrapyramidal nervous system) for extrapyramidal symptoms, and the level hypothalamic 'tuberoinfundibular' system for adverse effects, neuroendocrine [2].

The difference between antipsychotics, typical and atypical is their affinity date for receptors D2 (Table 1) [3].

Degree of occupation, of receptor D2 the basal ganglia and the cortical receptors 5HT2, PET-Positron emission tomography, SPECTsingle-photon emission computed tomography ${ }^{1}$ (Table 1).

Medications such as Clozapine binds slowly and have a fast dissociation for receptors D2 compared to typical antipsychotics (such as Haloperidol) which have a strong affinity for these receptors. Some researchers have proposed that this rapid dissociation receptors D2 and reduced affinity for these receptors could explain clozapine atypias, resulting in a low affinity for dopamine receptors D2. The atypia's rapid dissociation rate is given by Koff for receptor dopamine D2 [4].

Clozapine it is the prototype of atypical antipsychotic. As it is known, Clozapine It was found to be the most effective treatment for chronic schizophrenia, it having the lowest level of receptor occupancy D2 through all antipsychotic medications. At very low doses $(50 \mathrm{mg} /$

\begin{tabular}{|c|c|c|c|}
\hline \multirow{2}{*}{ Antipsychotics } & The receptors profile & \multicolumn{2}{|c|}{ PET (SPECT) } \\
\cline { 3 - 4 } & D2 (\%) & 5-HT2 (\%) \\
\hline Haloperidol & Antagonist, in particular, receptor. D2 like & $70-90$ & 0 \\
\hline Amisulpride & Selective antagonist D2/3 & $38-76$ & 0 \\
\hline Clozapine & Multiple antagonist & $20-68$ & $84-100$ \\
\hline Olanzapine & Multiple antagonist & $43-39$ & $90-100$ \\
\hline Quetiapine & Multiple antagonist & $22-68$ & $48-70$ \\
\hline Risperidone & Antagonist 5-HT2/D2/a1 & $59-89$ & $78-100$ \\
\hline Sertindole & Antagonist 5-HT2/D2/a1 & $50-74$ & $(90+)$ \\
\hline Ziprasidone & Antagonist 5-HT2/D2/a1+Antagonist & 77 & 95 \\
\hline Zotepine & 5HT1A+reuptake NA/5HT & & $?$ \\
\hline
\end{tabular}

Table 1: Comparison between pharmacological profile typical antipsychotics and second generation*. day), lower than the usual doses used to obtain antipsychotic effect, it observed a complete occupancy for the system 5HT2. The efficacy of clozapine in refractory patients to be observed in the dose range $300-400 \mathrm{ng} / \mathrm{ml}$, where occupancy receptors D2 it is between $50-60 \%$. This reduced level occupancy of receptors. D2 explain why not give Clozapine EPS or significant increases in prolactin. Binding profile of the Olanzapine It is similar to the Clozapine, reality supported by studies PET [5].

Risperidone It becomes efficacious therapeutic levels of occupancy D2 observer usual to typical antipsychotics (at a dose of $2 \mathrm{mg}$ develop an occupancy of D2 by $60 \%$ or bigger). High levels of occupancy of $5 \mathrm{HT} 2$ They were observed even at low doses, but they do not result from antipsychotic effect [6].

Olanzapine He showed a preferential blocking of the receptors $5 \mathrm{HT} 2$ comparable dopamine receptors D2. The antipsychotic effect is usually seen at a dose between $10-20 \mathrm{mg} /$ day, when the occupancy rate of $\mathrm{D} 2$ achieve $65-80 \%$. At dosages of $30 \mathrm{mg} /$ day or larger, then they increase in prolactin levels and EPS, occupancy threshold, exceeded the $80 \%$. Amisulpride, unlike other antipsychotic has no affinity for the serotonin receptors 5HT2. Doses of Amisulpride between 600-900 $\mathrm{mg} /$ day give occupancy rate $\mathrm{D} 2$ of $70-80 \%$, while the doses $>1100 \mathrm{mg} /$ day give occupancy rate $\mathrm{D} 2$ of $>85 \%$, and at these higher doses may be observed EPS. Blocking the receptors 5HT2A and preferential blocking certain subtypes of dopamine receptors it was an assumption relevant in defining the mechanism effectiveness atypical or second generation antipsychotics in the treatment of negative symptoms [7]. The studies PET of atypical antipsychotics showed an extended of the receptors occupancy rate 5HT2A in the cerebral cortex clozapine, olanzapine, risperidone and quetiapine, but not amisulpride. The difference observed between receptors occupancy and active clinical doses lead to the question whether the effect on receptors 5HT2A It is the sole determinant of neurochemical atypia [8].

In conclusion, can affirm that, numerous research techniques increasingly more laborious find answers to some questions but have raised some new ones, developing new lines of research. Once again, the human brain proves to be a universe to be further explored, schizophrenia and remained an enigma, only partially loosed.

*Corresponding author: Butnariu M, Professor, Habilitated Doctor, Chemist, Chemistry and Biochemistry Discipline, Banat's University of Agricultural Sciences and Veterinary Medicine "King Michael I of Romania" Timisoara, 300645, Calea Aradului 119, Timis, Romania, Tel: 004-0256-277464; Fax: 004-0256-200296; E-mail: monicabutnariu@yahoo.com

Received February 20, 2017; Accepted February 21, 2017; Published March 03, 2017

Citation: Butnariu M (2017) Bioequivalence and Bioavailability of Receptors Dopamine (D2) and Serotonin in the Action of Antipsychotic Drugs. J Bioequiv Availab 9: e76. doi:10.4172/jbb.10000e76

Copyright: @ 2017 Butnariu M. This is an open-access article distributed under the terms of the Creative Commons Attribution License, which permits unrestricted use, distribution, and reproduction in any medium, provided the original author and source are credited. 
Citation: Butnariu M (2017) Bioequivalence and Bioavailability of Receptors Dopamine (D2) and Serotonin in the Action of Antipsychotic Drugs. J Bioequiv Availab 9: e76. doi:10.4172/jbb.10000e76

\section{References}

1. Genis-Mendoza AD, Tovilla-Zárate CA, López-Narvaez L, Mendoza-Lorenzo P, Ostrosky-Wegman P, et al. (2016) Effect on the expression of drd2 and drd3 after neonatal lesion in the lymphocytes, nucleus accumbens, hippocampus and prefrontal cortex: comparative analysis between juvenile and adult Wistar rats. Hereditas 153: 13

2. Lee AG, Nechvatal JM, Shen B, Buckmaster CL, Levy MJ, et al. (2016) Striatal dopamine $\mathrm{D} 2 / 3$ receptor regulation by stress inoculation in squirrel monkeys. Neurobiol Stress 3: 68-73.

3. Fuchigami T, Nakayama M, Yoshida S (2015) "Development of PET and SPECT Probes for Glutamate Receptors. Sci World J 2015: 716514.

4. Mamaligas AA, Cai Y, Ford CP (2016) Nicotinic and opioid receptor regulation of striatal dopamine D2-receptor mediated transmission. Sci Rep 6: 37834.
5. Kristóf E, Doan-Xuan QM, Sárvári AK, Klusóczki Á, Fischer-Posovszky P, et al. (2016) Clozapine modifies the differentiation program of human adipocytes inducing browning. Transl Psychiatry 2016 6: e963.

6. Tadokoro S, Nonomura N, Kanahara N, Hashimoto K, lyo M, et al. (2017) Reduction of Severity of Recurrent Psychotic Episode by Sustained Treatment with Aripiprazole in a Schizophrenic Patient with Dopamine Supersensitivity: A Case Report. Clin Psychopharmacol Neurosci 15: 79-81.

7. Johnson KA, Mateo Y, Lovinger DM (2017) Metabotropic glutamate recepto 2 inhibits thalamically-driven glutamate and dopamine release in the dorsal striatum. Neuropharmacology 117: 114-123.

8. Brust TF, Hayes MP, Roman DL, Watts VJ (2015) New functional activity of aripiprazole revealed: Robust antagonism of D2 dopamine receptor-stimulated Gßy signaling. Biochem Pharmacol 93: 85-91. 